chlorambucil have been implicated in the emergence of a terminal acute leukaemia in CLL. ${ }^{4}$

So far as we know AML and CLL occurring together without previous treatment has only once been reported previously. ${ }^{5}$ The CLL was, perhaps, temporarily suppressed but seemed to have been relatively unaffected by the treatment of AML. Indeed, this patient with well documented AML has done extraordinarily well to be still in remission five years after what some would consider to be a mild form of treatment. Any immunological suppression associated with his CLL obviously did not preclude him from keeping the AML in check.

We thank Professor T A J Prankerd and Dr J D M Richards for permission to report this case.

${ }^{1}$ Greaves, M F, and Brown, G, Nature New Biology, 1973, 246, 116.

2 McPhedran, P, and Heath, C W, Blood, 1970, 35, 7.

3 Brouet, J C, et al, British Medical fournal, 1973, 4, 23.

${ }^{4}$ Catovsky, D, and Galton, D A G, British Medical fournal, 1973, 4, 23.

${ }^{5}$ Roberts, P O, and Forster, P M, British fournal of Haematology, 1973, 25, 203.

Department of Haematology, University College Hospital, London WC1 6AU

R WARWICK, $M B, C H B$, registrar

A H GOLDSTONE, MRCP, MRCPATH, consultant haematologist

G JANOSSY, MD, PHD, research fellow

\section{Association between previous tuberculous infection and glioma}

In view of the possible role of depressed immunity in the pathogenesis of neoplasia we investigated 300 patients with cerebral glioma and 300 controls to see if there was any association between previous tuberculous infection and glioma.

\section{Patients, methods, and results}

Chest $x$-ray films of 300 consecutive patients with histologically proved glioma of the brain were reviewed for evidence of previous pulmonary tuberculosis. Based on the results the patients were divided into those with only a calcified primary complex or one of its components, and those who had had either progressive primary or postprimary disease. Controls were 300 patients aged over 40 who were seen consecutively during the survey period and examination of whom had excluded any likelihood of malignant disease. Altogether 144 had spinal conditions, of which 111 were either disc lesions or spondylosis; 123 intracranial lesions (the commonest diagnosis being subarachnoid haemorrhage), and 33 peripheral neurological lesions. The table gives the age and sex distribution of the patients and controls.

Of the patients with glioma, $22(7 \cdot 3 \%)$ had evidence of previous primary tuberculosis, and $28(9 \cdot 3 \%)$ evidence of either progressive primary or post- primary infection. The corresponding figures among the controls were 28 $(9 \cdot 3 \%)$ and $31(10 \cdot 3 \%)$ respectively (see table).

\section{Discussion}

Impaired immunity may predispose to neoplasia in the same way as it does to infections. ${ }^{1-3}$ Burnet, ${ }^{4}$ for example, pointed out the increased prevalence of cancer in the perinatal period and in old age, when immunity is impaired. Lymphomas have developed in patients receiving immunosuppressives, and there is an increased prevalence of neoplasms in certain genetic immunity deficiency states. It has also been suggested that a neoplasm may form as a result of the immunological responses brought about by a chronic infection such as tuberculosis. ${ }^{3}$

Sutherland ${ }^{5}$ reported an increased mortality from malignant neoplasm (including cerebral) in patients who were tuberculinpositive as compared with those who were tuberculin-negative on entry to the tuberculosis vaccines trial, but there was no increased incidence of malignant neoplasm in the group given BCG. He suggested that the higher mortality from neoplasm in those who had had a previous natural mycobacterial infection was therefore more likely to be related to some aspect of the environment in which it occurred than to represent an immunological consequence of that infection.

Ward $e t a l^{3}$ reviewed the case histories and chest $x$-ray films of 92 patients with cerebral glioma and compared the findings with those in controls who were over the age of 50 and who had been admitted consecutively to general medical units. They found that $21.7 \%$ of the patients with glioma had either a history of previous tuberculosis or evidence of healed fibrotic lesions on their $x$-ray films as compared with $7 \%$ of the controls. They suggested that the patients with normal immune responses had dealt rapidly with a primary tuberculous infection, so that it had left no evidence other than perhaps a healed primary focus. Those with impaired immunity had possibly had more difficulty in dealing with the infection, which had therefore taken a moreprolonged course.

In our larger series, in which the controls, like the patients, had neurological complaints and were more nearly comparable in age, there was no evidence to suggest that previous pulmonary tuberculous infection in any form was related to the subsequent development of glioma.

I am grateful to colleagues at the Institute of Neurological Sciences for criticism of this paper.

${ }^{1}$ Gatti, R A, and Good, R A, in Proceedings of 10th International Cancer Research Congress, Houston, 1970, vol 1, $\mathrm{p} 803$.

${ }^{2}$ Lancet, 1971, 2, 143.

${ }^{3}$ Ward, D W, Mattison, M L, and Finn, R, British Medical fournal, 1973, $1,83$.

${ }^{4}$ Burnet, M, Immunological Surveillance. Oxford, Pergamon, 1972.

${ }^{5}$ Sutherland, I, British Medical fournal, 1973, 1, 419.

Institute of Neurological Sciences, Southern General Hospital, Glasgow G51 4TF

P MACPHERSON, FRCR, DTCD, consultant neuroradiologist

Age and sex distribution of 300 patients with glioma and 300 controls in relation to evidence of previous pulmonary tuberculosis

\begin{tabular}{|c|c|c|c|c|c|c|c|c|c|c|c|c|c|c|c|c|}
\hline & & \multicolumn{3}{|c|}{ Aged $<\mathbf{4 0}$} & \multicolumn{3}{|c|}{ Aged 40- } & \multicolumn{3}{|c|}{ Aged 50- } & \multicolumn{3}{|c|}{ Aged $\geqslant 60$} & \multicolumn{3}{|c|}{ Total } \\
\hline & & $\mathbf{N}$ & $\mathbf{P}$ & PP & $\mathrm{N}$ & $\mathbf{P}$ & PP & $\mathrm{N}$ & $\mathbf{P}$ & PP & $\mathbf{N}$ & $\mathbf{P}$ & PP & $\mathrm{N}$ & $\mathbf{P}$ & PP \\
\hline \multicolumn{17}{|c|}{ Patients with glioma } \\
\hline $\begin{array}{l}\text { Men } \\
\text { Women }\end{array}$ & .. & $\begin{array}{l}36 \\
22\end{array}$ & $\frac{1}{5}$ & $\begin{array}{l}3 \\
1\end{array}$ & $\begin{array}{l}25 \\
23\end{array}$ & $\begin{array}{l}1 \\
1\end{array}$ & $\begin{array}{l}1 \\
1\end{array}$ & $\begin{array}{l}35 \\
28\end{array}$ & $\begin{array}{l}4 \\
4\end{array}$ & $\begin{array}{l}5 \\
4\end{array}$ & $\begin{array}{l}50 \\
31\end{array}$ & $\begin{array}{l}2 \\
4\end{array}$ & $\begin{array}{l}8 \\
5\end{array}$ & $\begin{array}{l}146 \\
104\end{array}$ & $\begin{array}{r}8(4.7 \%) \\
14(10.9 \%)\end{array}$ & $\begin{array}{l}17(10 \%) \\
11(8.5 \%)\end{array}$ \\
\hline & & 58 & 6 & 4 & 48 & 2 & 2 & 63 & 8 & 9 & 81 & 6 & 13 & 250 & $22(7.3 \%)$ & $28(9 \cdot 3 \%)$ \\
\hline \multicolumn{17}{|c|}{ Controls } \\
\hline $\begin{array}{l}\text { Men } \\
\text { Women }\end{array}$ & .. & & & & $\begin{array}{l}43 \\
42\end{array}$ & $\begin{array}{l}5 \\
4\end{array}$ & $\begin{array}{l}6 \\
8\end{array}$ & $\begin{array}{l}44 \\
26\end{array}$ & $\frac{2}{7}$ & $\begin{array}{l}6 \\
4\end{array}$ & $\begin{array}{l}48 \\
38\end{array}$ & $\begin{array}{l}6 \\
4\end{array}$ & $\begin{array}{l}5 \\
2\end{array}$ & $\begin{array}{l}135 \\
106\end{array}$ & $\begin{array}{l}13(7.9 \%) \\
15(11 \cdot 1 \%)\end{array}$ & $\begin{array}{l}17(10.3 \%) \\
14(10.4 \%)\end{array}$ \\
\hline & & & & & 85 & 9 & 14 & 70 & 9 & 10 & 86 & 10 & 7 & 241 & $28(9 \cdot 3 \%)$ & $31(10.3 \%)$ \\
\hline
\end{tabular}

$\mathbf{N}=$ No evidence of pulmonary tuberculosis. $\mathbf{P}=$ Primary pulmonary tuberculosis. $\mathbf{P P}=$ Progressive and postprimary pulmonary tuberculosis. 